\title{
ASSESSMENT OF IMPACT OF FORMAT OF RETAIL INTERNATIONALIZATION ON CONSUMER ATTITUDE
}

\author{
Elzė Rudiene் ${ }^{1}$, Mangirdas Morkūnas ${ }^{2}$, Viktorija Skvarciany ${ }^{3}$ \\ ${ }^{1}$ Business School, Vilnius University, Sauletekio Ave. 22, Vilnius, Lithuania \\ ${ }^{2}$ Faculty of Economics and Business Administration, Vilnius University, \\ Sauletekio Ave. 9, Vilnius, Lithuania \\ ${ }^{3}$ Department of Economics Engineering, Faculty of Business Management, \\ Vilnius Gediminas Technical University, Sauletekio Ave. 11, Vilnius, Lithuania \\ Email: ${ }^{1}$ elze.rudiene@gmail.com; ${ }^{2}$ morkunas.mangirdas@gmail.com; \\ ${ }^{3}$ viktorija.skvarciany@vgtu.lt (corresponding author)
}

\begin{abstract}
The format is one of the essential elements of retail internationalization process. In order to date, customer attitude about retail companies format entering the market and their possible impact upon consumers and standardization degree has not frequently been the object of investigation within the internationalisation of retail trade. Only by opening the subject of trade consumers and customers can find the solution of components of this element. The current paper explores consumer attitudes to retail format, revealed this element components and provide their evaluation methodology. The practical significance of the current research is that it is a survey of consumer attitude to the company entering format the market in another country, which would enable a potential retail entrant to know the expectations of consumers and thus take appropriate decisions. The methodological basis for the present paper is an analysis of reference material on the internationalisation of retail trade examining cases of successes and failures of retail companies, exploring and understanding consumer expectations and the ways to meet such expectations, as well as peculiarities of entering different markets. The authors interviewed Lithuanian consumers (more than 600) about the IKEA shopping centre before its opening in Vilnius and one year after opening. Studies have confirmed that consumers have their attitudes of the IKEA shopping centre, as the format element.
\end{abstract}

Keywords: format, retail internationalization, customer, retailer.

JEL Classification: M20.

\section{Introduction}

The concept of a commercial entity format is of a rather general nature, i.e. provides a classification of the types and a description of each such type. Most researchers use the term 'format' as a means to describe a trade centre (hypermarket, supermarket) or a discount system thereby, however, according to Dawson and Mukoyama (2014), the term is not sufficiently accurate. In their view, a commercial entity format has two key meanings. The first meaning is general and to a degree less defined, perceived as a general and most frequent definition, that immediately comes into anybody's mind - a trade centre, a department store, a supermarket. The general format of a commercial entity significantly lacks specificity, although such format is perceived by each of us in a personal specific way. Another interpretation of a commercial entity format targets a specific company of a host country, e.g. discount stores managed by Wal-Mart or a trade centre managed by Carrefour.
Mukoyama and Dawson (2006, 2014) claim that the most international retailers (food products, non-food products and other sectors) operate through more than one commercial entity format in their home country. A number of companies, such as Carrefour, Tesco, Wal-Mart, Lidl, Ahold, Auchan and others, develop their operations in foreign markets and are multi-format in their own home market. Apparently, market participants operate in a similar mode in other sectors, although at a smaller scale. Proper examples of such entities could be Zara, Gap, Marks\&Spencer, Benetton and other retail trade stores. That is related to a degree to which companies adapt their stores in foreign markets. The authors of the present paper emphasised that food product stores have fewer possibilities to standardize a commercial entity type in foreign countries. For instance, Carrefour trade centre open in Japan is different from a Carrefour outlet in France, because the location requires a different communication with the local

(C) 2018 The Authors. Published by VGTU Press. This is an open-access article distributed under the terms of the Creative Commons Attribution License (CC-BY 4.0), which permits unrestricted use, distribution, and reproduction in any medium, provided the original author and source are credited. 
consumers through the elements of marking, layout of the goods and other variables of the trade centre format. The specific features of the identical commercial entity type depend on the country (see Table 1).

Table 1. Commercial entity format and its expression (source: Mukoyama \& Dawson, 2006, 2014)

\begin{tabular}{|c|c|c|c|}
\hline \multirow{3}{*}{$\begin{array}{c}\text { Com- } \\
\text { mer- } \\
\text { cial } \\
\text { entity } \\
\text { format }\end{array}$} & \multicolumn{2}{|c|}{ Characteristics } & Example \\
\hline & \multirow{2}{*}{\multicolumn{2}{|c|}{$\begin{array}{c}\text { Universal, general, } \\
\text { abstract }\end{array}$}} & $\begin{array}{l}\text { Hypermarket/ } \\
\text { Supermarket }\end{array}$ \\
\hline & & & $\begin{array}{l}\text { Discount store/ } \\
\text { Vending machine }\end{array}$ \\
\hline \multirow{8}{*}{$\begin{array}{l}\text { Ex- } \\
\text { pres- } \\
\text { sion } \\
\text { of the } \\
\text { com- } \\
\text { mer- } \\
\text { cial } \\
\text { entity } \\
\text { format }\end{array}$} & \multirow{8}{*}{$\begin{array}{l}\text { Spe- } \\
\text { cific, } \\
\text { situa- } \\
\text { tional, } \\
\text { notable }\end{array}$} & \multirow{2}{*}{$\begin{array}{l}\text { Peculia- } \\
\text { rity of } \\
\text { the com- } \\
\text { pany } \\
\text { and the } \\
\text { home } \\
\text { country }\end{array}$} & $\begin{array}{l}\text { Tesco Hypermar- } \\
\text { ket formula in } \\
\text { Great Britain }\end{array}$ \\
\hline & & & $\begin{array}{l}\text { Carrefour Hyper- } \\
\text { market formula in } \\
\text { France }\end{array}$ \\
\hline & & \multirow{6}{*}{$\begin{array}{l}\text { Peculia- } \\
\text { rity of } \\
\text { the com- } \\
\text { pany } \\
\text { and the } \\
\text { country } \\
\text { of entry }\end{array}$} & $\begin{array}{l}\text { Tesco Hypermar- } \\
\text { ket formula in } \\
\text { Taiwan }\end{array}$ \\
\hline & & & $\begin{array}{l}\text { Tesco Hypermar- } \\
\text { ket formula in } \\
\text { Korea }\end{array}$ \\
\hline & & & $\begin{array}{l}\text { Tesco Hypermar- } \\
\text { ket formula in } \\
\text { Hungary }\end{array}$ \\
\hline & & & $\begin{array}{l}\text { Carrefour Hyper- } \\
\text { market formula in } \\
\text { Taiwan }\end{array}$ \\
\hline & & & $\begin{array}{l}\text { Carrefour Hyper- } \\
\text { market formula in } \\
\text { Korea }\end{array}$ \\
\hline & & & $\begin{array}{l}\text { Carrefour Hyper- } \\
\text { market formula in } \\
\text { Japan }\end{array}$ \\
\hline
\end{tabular}

Dupuis and Prime (1995) claim that the choice of a commercial entity format is affected by the cultural environment of the country, and a selected strategy of internationalisation, as well as the financial capacities of a retail company entering a national market. The diversity of commercial entity formats and their transformation shows the importance of the retail trade internationalisation process, as well as its interface with other elements. Swoboda and Elsner (2013) explained and substantiated the potential impact of a commercial entity transposed to another country upon marketing and supply chain processes. They claimed that the degree of standardisation of a commercial entity is transferred to another country determines the degree of standardisation of the principal elements of marketing and the supply processes. The attitudes and the processes are viewed from the positions of the retail trade company. Since the central figure in the retail trade internationalisation process is the consumer, the aim of the survey is to determine whether or not the consumers have an impact upon the selected trade format of a retail trade company. In other words, the aim was to establish whether or not retailers study the attitudes of consumers towards the commercial entity format, or take such attitudes into account when making selections. It might be explained as a commercial secret of retailers, as research publications on the subject are very scarce, and those existing mostly deal with the development of formats in individual regions of the world and the countries. It could be also the case that retailers in one way or another are interested in the attitudes of consumers, and their opinions about an acceptable commercial entity format, while others rely on their international expertise. Therefore, some consumers welcome the commercial entity format selected by consumers, others remain neutral or assess negatively, which eventually may be a reason for not attending the trade objects.

To evaluate the impact of a type of sales object format on consumer preferences, it is necessary to extract the components of this factor, i.e. what forms are most important for the user's preferences.

The object of the research is the type of object format.

The purpose of the article is to evaluate the impact of the type of object format on consumer preferences.

The goal is to achieve the following objectives:

- Consumers have their own point of view about the type of retail company coming

- The most important components of the object type impact on consumer regulations are justified

- Methodology for assessing the impact of the type of trade object type on consumer regulations

- A survey of Lithuanian consumers of IKEA centre in Vilnius was carried out as an assessment of the impact of object format on their provisions.

Methodology for the purpose of analysis of the format in internationalization process, retailers' failure and success stories, and consumer expectations the authors of the present paper used 
general research methods, i.e. analysis of the relevant scientific literature, comparative and systematic logical analysis.

\section{Theoretical background and aspects of the formation of consumer attitudes}

A lack of articles or other publications specifically dealing with the attributes of consumer attitudes towards a trading company entering the market were found, there are some interesting publications on the selection of a commercial entity format, success or other cases. Thus Dupuis and Prime (1995) confirmed the statement as earlier specified regarding the impact upon the choice of a store (commercial entity format) of the cultural environment of the country and the selected internationalisation strategy. J. Fernie and S. Fernie (1997) were investigating the development of the American format in the context of the British retail market; while Arnold (2000) attempted to assess the prospect of Wal-Mart format in Great Britain. Indirectly that would mean that the commercial entity formats of retail companies in other states were accepted in Europe, Great Britain. Goldman $(2000,2001)$ covered the problems in the Chinese market arising having selected a specific type of the commercial entity format of a shopping centre, or a store. Some commercial entity formats appeared to be excessively large and encountered difficulties in ensuring proper supply of the objects. Not all new retail trade companies managed to properly consider the lower level of development of the country, the shopping habits of the consumers, as well as other important items. Guy (2001) was studying the impact of the formats of large trade objects on leisure time habits in Western Europe. Burt, Davies, McAuley, and Sparks (2005), Humphrey (2007), Reardon, Henson, and Berdegue (2007), White'as and Absheris (2007), Burt, Davies, Dawson, and Sparks (2008), Ahlert, Blut, and Evanschitzky (2010), Hallsworth, de Kervenoael, Elms, and Canning (2010), Gorton, Sauer, and Supatpongkul (2011), Swoboda, Berg, and Dabija (2014) studied the process of implementing retail commercial entity formats within the framework of retail trade internationalisation in specific regions of the world, changes in trade centres in developed countries, and the evolution of commercial entity formats in the future. Gandolfi and Strach (2009) studied the experimental experience of the Wal-Mart shopping centre in South Korea, Jonsson (2010) summarised the prospects for internationalisation of the IKEA centre. Minahan, Huddleston, and Bianchi (2012) carried out social studies among consumers in Melbourn inquiring their views about an American retail trade company Costco. Some consumers noted that although the shopping centre was opened in a renovated section of the city, however, the location itself is hardly known to customers, it is in a fairly large distance, inconvenient to reach by public transportation and always presenting a challenge in terms of parking. The consumers then heartily welcomed the abundance of additional services that attracted families for spending leisure time. Lowe and Wrigley (2009) were studying the investment of the Tesco retail trade company in the USA market. Having carried out some consumer surveys the trading company developed new 'fresh and easy' store type that guaranteed the store's entry into the USA trade market. The entire entry process lasted for nearly three years and required significant investment.

A summary of commercial entity formats as covered in scientific literature in different regions of the world yielded the following conclusions:

Retail trade companies operating in other states face the challenges of selecting commercial entity type or implementing it.

Ordinarily, consumer surveys are carried out immediately after the opening of a trading entity when the object faces dissatisfaction on the part of consumers;

While adopting a commercial entity type of a retail trade company having regard to the differences of consumers within a country, it often needs to be adapted to the peculiarity of the country, i.e. modified;

The commercial entity format directly affects consumers, but naturally, to a different degree;

The attitude of a consumer towards a commercial entity format is shaped by the object's location, size, layout, parking facilities, internal layout or additional services the object can offer.

It is necessary to note that the factors shaping the evaluation of food stores in Lithuania and abroad presented in the survey Shopper trend (2015) produced by Nielsen company in Lithuania are similar to those identified in relation to the analysis of literature. Stores are described in terms of the convenience in parking cars, the capacity of a store, impeccable services and pleasant environment.

Four key attributes (see Figure 1) of the impact of a commercial entity format upon consumers were identified based on the literary sources and the results of the analysis conducted by a survey company Nielsen. In other words, the four attributes contribute to building each consumer's 
attitude towards a commercial entity format. Furthermore, as seen in Figure 1, an understanding of each attribute may differ depending on the country.

It is specifically these elements that influence the consumer's attitudes towards the type of a trading location and helps the consumers to create a picture in their minds about a store or a trade centre, without having seen it. Under equal conditions, consumers not infrequently prefer and seek a different commercial entity format: a geographical location or a size of the trading floor, a convenient layout of the building. There are two groups of attributes have been distinguished with respect to a convenient location: a geographical location, access methods and time. The format and the size of a commercial entity are defined in terms of the area (square metres) of a trading floor, and the structure of the layout of the building. The attributes of a convenient car park at a commercial entity are also broken down into two groups: types of the car park, the time required to park a car and reaching the store. The two groups of the attributes should fully describe and disclose the level of convenience of a car park. Identifying the attributes of the attractiveness of the exterior and interior of a commercial entity format is a somewhat more challenging task, as the concepts are hardly understandable for most consumers. It is expected, though, that individually identified attributes of the exterior and interior will help the consumers to assess their visual parameters. With a view to identifying the necessity of additional services first paid and free services need to be identified. The diversity and the scope of additional services may differ depending on the country. For the purpose of the present paper, the authors distinguished the most important additional basic services most needed for consumers.

A possible impact of a commercial entity format upon consumers can be derived from the answers to a questionnaire compiled based on the main attributes of a commercial entity format and following the developed methodology.

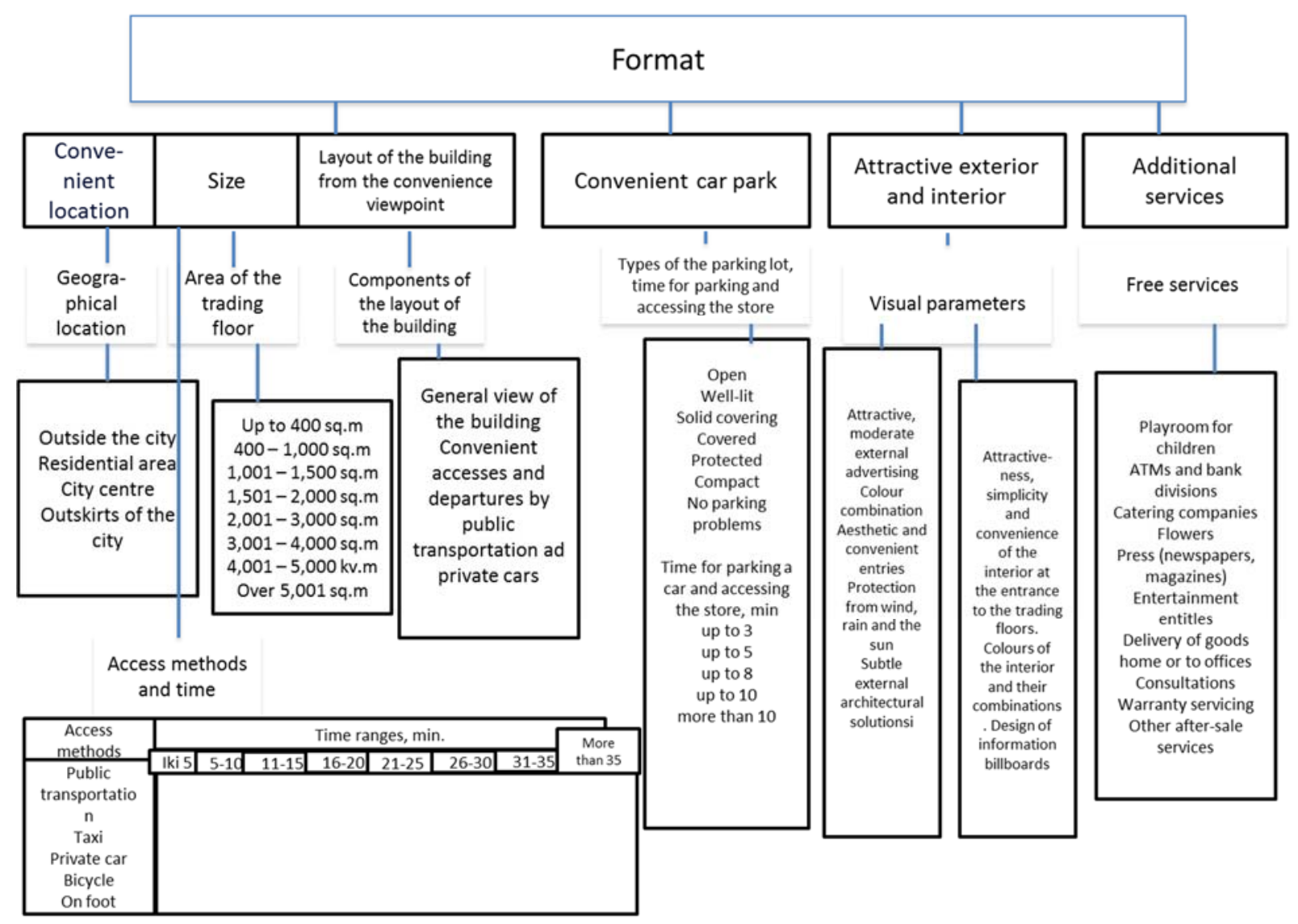

Figure 1. Forms of the direct impact of the commercial entity format upon consumers (source: created by authors) 


\section{Purpose and methodology of the study}

The purpose of the study was to determine the possible impact of the type of commercial object format of IKEA on consumers. In order to achieve the stated goal, the following tasks were set and implemented:

1. To find out the level of exposure of certain factors according to the characteristics of respondents and knowledge of IKEA shopping centre.

2. Determine the strength of the impact of IKEA as a marketing object type factor on consumers.

3. Determine the strength of the impact of IKEA as a trade item type factor element on consumers.

As one of the findings during the first study was that part of the respondents have never been to IKEA trade centres in other countries, and the results of the second study indicated that some of the respondents have never visited the IKEA centre in Vilnius as a commercial entity format, the following hypothesis was offered (H1):

The expectations of and the impact upon the consumers who have never visited the IKEA centre in Vilnius as a commercial entity format will be less significant than those who have visited the centre.

The theoretical justification of the research methodology is based on the features of the potential impact of the type of object format formulated in Figure 1. The applied quantitative method of consumer survey allows revealing the influence of the type of trade object format factor and its elements on the strength. The potential influence of IKEA as a type of object format on consumer regulations was explored. The first study was conducted just before the opening of IKEA centre in Vilnius, and the second one a year after its opening. The questionnaire was prepared on the basis of questionnaire guidelines in order to provide a comprehensive answer to the questions and achieve the purpose of the survey. A lot of attention was paid to respondents' social factors that would show their distribution according to the characteristics and knowledge of IKEA and to determine whether the potential impact of users is influenced by gender, age, education and knowledge of IKEA. The most complicated question is the determination of the level of exposure of consumers to each element of the object format of IKEA. It is equally important to provide a method for calculating the level of impact of a complex object- format on the level of consumers.

In order to obtain statistically reliable research results that reflect the characteristics of the general population, appropriate respondents should be selected. The survey did not include persons under the age of 18. Although they have an influence on making purchasing decisions, they are not buyers of IKEA centre.

The respondents were selected by way of probability stratified sampling method, because the population is not homogeneous, and can be broken down into strata. Respondents from all towns and cities of Lithuania took part in the study.

The same study was conducted one year after the start of IKEA centre. The main purpose of the repeat survey is to involve more than half of the same respondents who participated in the first survey. This kind of survey would allow more accurate data systematization and better reflect the possible impact and assessment.

As was earlier pointed out a factor of a commercial entity format is made up of four elements and five estimate sections. The breakdown may be expressed as $\mathrm{Vnvi}=(\mathrm{Vn} / 4) / 5$; where Vnvi - mean of the $\mathrm{n}$ factor with respect to the number of factors and the estimate sections; $\mathrm{Vn}$ - mean of the $\mathrm{n}$ factor; 4 - the number of factors; 5 - the number of estimate sections.

In this specific case the coefficient of the complex impact is:

$\mathrm{F}_{\mathrm{k}}=\left(\mathrm{F}_{1} / 4\right) / 5+\left(\mathrm{F}_{2} / 4\right) 5+\left(\mathrm{F}_{3} / 4\right) / 5+\left(\mathrm{F}_{4} / 4\right) / 5 ;$

where $F_{k}$ - coefficient of the complex impact of the group of factors of a commercial entity format; $F_{1,2,3,4}-$ mean of the first, second, third and fourth element of the group of the commercial entity format; 4 - total elements; 5 - total estimate sections.

The coefficient of the complex impact of the group of factors of a commercial entity format may not be higher than 1 , and that of each element is 0.25 . A more comprehensive and/or accurate survey can be carried out by comparing the coefficient of the complex impact of the commercial entity format with the maximum possible coefficient.

\section{Results of the first survey and its evaluation}

The first survey of the future consumers of Lithuanian IKEA shopping centre was conducted in August 2013, before the opening of the furniture retail centre "IKEA" The survey involved 698 respondents. Only 663 questionnaires were considered appropriate. Because of respondents who have not marked their gender (even 64 of them), it is not possible to give a precise statistics on their gender by gender criteria. It should be emphasized 
that nearly $30 \%$ of respondents who visited IKEA supermarkets in other countries took part in this survey. As a result, this group of respondents was separated from others when rendering the results. The socio-demographic characteristics of respondents who participated in the survey are presented in Figure 2.

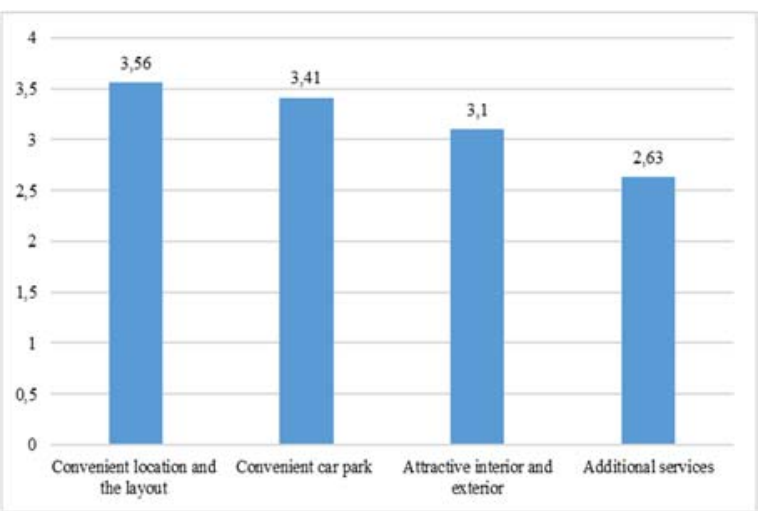

Figure 2. Averages of the impact of the characteristics of the commercial entity format of the IKEA trade centre upon the decisions of the consumers (source: created by authors)

Respondents' scale is quite broad talking in terms of their education. As it can be seen, almost two-thirds of respondents who participated in the survey hold a higher education degree.

Analysing the respondents' answers to the statement "Do you know that IKEA shopping centre will be opened in Vilnius," there was no statistically significant difference in results based on gender $(p=0,108)$ About the opening of the IKEA shopping centre in Vilnius knew $56.5 \%$ of men $(\mathrm{N}=288)$ and $43.5 \%$ of women $(\mathrm{N}=222)$.

Respondents were asked to evaluate on a 5 -point scale, with 5 being the most significant, the influence of a particular factor on consumer approach to the opening of the shopping centre IKEA.

From the answers to the question which features of the IKEA shopping centre are important for consumer decisions to visit the supermarket (survey conducted before its opening), it has been revealed that the convenient location and layout are considered as the most important factors (3.5 points).

The most important factors include a comfortable parking lot (3.4 points), less important additional services ( 2.6 points).

The low score for additional services can be explained by the subjective perception of each user. Of course, this can be said about every element of this factor, but it essentially reflects the emerging consumer attitude towards the opening of the IKEA supermarket as a type of marketing object that may change after it will be visited.

Thus, in summarizing the answers, it can be stated in advance that consumer decisions are influenced by the location of the supermarket, access and parking options, in other words, the convenience factor.

The Mann and Whitney tests have been calculated to determine whether respondents rated the features of the IKEA shopping centre according to their gender. The resulting $\mathrm{p}$ values are shown in Table 2.

Table 2. Manno and Whitney test (source: authours' calculations)

\begin{tabular}{|c|c|c|c|c|}
\hline $\begin{array}{c}\text { Manno } \\
\text { and } \\
\begin{array}{c}\text { Whit- } \\
\text { ney test }\end{array}\end{array}$ & $\begin{array}{c}\text { Conven- } \\
\text { ient loca- } \\
\text { tion, size } \\
\text { and layout } \\
\text { of the } \\
\text { building }\end{array}$ & $\begin{array}{c}\text { Attrac- } \\
\text { tive in- } \\
\text { terior } \\
\text { and ex- } \\
\text { terior }\end{array}$ & $\begin{array}{c}\text { Car } \\
\text { park }\end{array}$ & $\begin{array}{c}\text { Addi- } \\
\text { tional } \\
\text { ser- } \\
\text { vices }\end{array}$ \\
\hline $\begin{array}{l}\text { Asymp. } \\
\text { Sig. }(2- \\
\text { tailed) }\end{array}$ & 0.009 & 0.902 & 0.082 & 0.455 \\
\hline
\end{tabular}

The results show that for men (mean rank $=$ 110.61), the convenience of a supermarket is more important than for women (mean rank $=90,19$ ); $p$-value is $0.009<0.05$. This is partly due to the fact that men are more likely to drive a car more often than women. On the other hand, it is natural that respondents of different genders appreciate different features of the IKEA supermarket.

\section{Results of the second survey and its evaluation}

One year after IKEA centre was opened, the second survey of Lithuanian consumers was conducted.

The survey involved 925 respondents. The number who visited $(\mathrm{N}=620)$ IKEA centre in Vilnius was $67 \%$ and not visited $-(\mathrm{N}=305)-33 \%$.

Socio-demographic characteristics of participants in the study. Of those who reported their data -520 women $(56.2 \%$ of all respondents in the study) and 369 (39.9\% of all respondents in the study) were men. 36 respondents don't respond of their gender $(4 \%)$.

By analyzing the distribution of the respondents who participated in the survey by occupation and the region in which the respondent was interviewed, it appears that the majority of them were 
specialists $-46 \%(\mathrm{~N}=410) .192$ respondents represented Vilnius city, 57 Kaunas, 23 Šiauliai region and 22 Utena region.

Statistically significant differences were found between the results of the survey of respondents who visited the IKEA centre and those who did not visit (see Table 3).

The average number of respondents who visited IKEA as a type of trading format exceeds 3 points for each item, i.e. ranging from 3.73 to 3.27 points for those who did not visit - respectively, exceeded 2 points, at an amplitude of 2.84-2.35 points. This confirmed the hypothesis. Since the average of both elements visited and not visited of each element varies from 0.89 to 0.92 , this can be explained by the following possible motivations of the respondents:

- A visit to the IKEA centre respondents helped them to prepare a final opinion on each element of the commercial entity form;

- The respondents who have never visited the IKEA centre have mostly affected public opinion about the negative aspects of the centre (distant, high prices, etc.).

It is worth noting that the means of each element assigned by the respondents who had earlier visited the IKEA centre as a commercial entity format exceeded three points, i.e. they were high. Except for the convenient location, size and the layout of the building such averages are higher than the averages of the three elements within the first survey.

The respondents who have visited the centre assigned the highest score (3.73) to the convenient car park, and the lowest score (3.27) was assigned to additional services. Such additional services may be best assessed only by the consumers who have bought anything from the IKEA centre and used one of the services provided thereby. Had the element been assessed only by the customers who had bought and used one service only, the result would have been more realistic, and the averages most probably would have been higher.

Since the average score of the convenient location, size and building layout element assigned by the respondents participating in the second survey, as compared with the first survey was different by ( -0.08 points) only, it could be concluded that the IKEA centre as a commercial entity format essentially met their expectations.

The overall combined effect of the second study was lowered by a lower coefficient of respondents who did not visit IKEA store. The second study, responding to the first study, is 0.0095 higher. The maximum coefficient may be 1.0, while the coefficients of the complex impact of respondents in the first and second survey are relatively high. It was influenced by the global experience of IKEA's retail company. On the other hand, the coefficients of the complex impact on consumer preferences show the potential for them to grow if the administration of the IKEA store is taking steps to improve the convenience of parking, changing the exterior elements of the building, and so on.

Table 3. The coefficient of the complex impact of the IKEA centre on the attitudes of the consumers computed for the first and second survey

\begin{tabular}{|l|c|c|}
\hline \multicolumn{1}{|c|}{$\begin{array}{c}\text { Name of } \\
\text { survey }\end{array}$} & $\begin{array}{c}\text { Coefficient of } \\
\text { the complex } \\
\text { impact }\end{array}$ & $\begin{array}{c}\text { Derogation } \\
\text { from the } \\
\text { maximum }\end{array}$ \\
\hline Survey I & 0.689 & -0.311 \\
\hline Survey II & 0.608 & -0.392 \\
\hline of which: & 0.6985 & -0.3015 \\
\hline $\begin{array}{l}\text { earlier visitors } \\
\text { to the centre }\end{array}$ & 0.5175 & -0.4825 \\
\hline Never visited & \\
\hline
\end{tabular}

The results of both surveys confirm that the company, its chosen type of trading format, affects the formation of consumer preferences.

\section{Conclusions}

Trade type of every retail company is generally a measure of the size of the trading space, and everything else can vary greatly. Even the type of retail entity in the same retailer may differ from country to country, with the exception of the size of the trading space.

Country consumers react in one way or another to the entering retailer, the type of format they choose to install. The consumer's perception of the type of trading object chosen by the trading company is gradually being developed. This is influenced by many factors, which distinguish common, arising from the general, specific characteristics of the individual entity, the phenomenon of consumer regulations to form.

The study of scientific literature does not explicitly consider the impact of a type of object format on consumer preferences. The same can be said about the components of the provision, i.e. elements. Such research can be done by the retail companies themselves, but it remains a commercial secret and the results are not publicly available. 
The analysis of the scientific literature on the type of trade objects format, their development and the attitude of consumers towards the individual elements of this factor, the analysis of the problem of the choice and implementation of retail companies in different regions of the world and in the countries has cleared out the four key elements that shape the user's view of the type of object format.

The research methodology is based on the formulation of the main features of the object format impact on consumers. The quantitative method of consumer and the methodology for calculating the coefficient of multiplication of the complexity of the trade object format is used.

The first survey of the yet-to-be customers of the IKEA trade centre in Lithuania was carried out immediately before the opening of the centre. 663 questionnaires were used for the study. The results of the survey confirmed that consumers have the idea of opening an IKEA as a type of object format. 3.56 out of 5 possible, the users have attributed - a convenient location, size, layout of the building. 3.41 points - comfortable parking, 3.10 - attractive interior and exterior, 2.63 points - additional services.

In the second study, conducted after the opening of the IKEA shopping centre, 925 respondents attended, of which $67 \%$ had visited IKEA for all types of object format impact on consumer preferences indicators averages significantly higher than those that did not go. This confirms the hypothesis raised. The biggest score 3.73 - users have placed a convenient parking. The results of the second study showed that it is expedient to conduct two consumer surveys to determine the type of trade object type - one before the opening of a trading object format, and another one after opening at least half a year. If the first study shows an emerging consumer attitude, then the second one is already formed.

The coefficient of the complexity of the respondents who visited the second survey, IKEA as a type of object format, is slightly higher than that of the first study. The high coefficient of complexity shows that the retail company IKEA essentially satisfied its consumer expectations with its type of trading object format.

\section{References}

Ahlert, D., Blut, M., \& Evanschitzky, H. (2010). Current status and future evolution of retail formats. In M. Kraft, M. K. Mantrala (Eds.), Retailing in the 21st century (2 ed.). Berlin Heidelberg: Springer.

https://doi.org/10.1007/978-3-540-72003-4_21
Arnold, S. J. (2000). Wal-Mart in Europe: prospects for the UK. International Marketing Review, 17(4/5), 416432. https://doi.org/10.1108/02651330010339932

Burt, S., Davies, K., Dawson, J., \& Sparks, L. (2008). Categorizing patterns and processes in retail grocery internationalization. Journal of Retailing and Consumer Services, 15(2), 78-92.

https://doi.org/10.1016/j.jretconser.2007.05.008

Burt, S., Davies, K., McAuley, A., \& Sparks, L. (2005). Retail internalization: from formats to implants. European Management Journal, 23(2), 195-202. https://doi.org/10.1016/j.emj.2005.02.006

Dawson, J., \& Mukoyama, M. (2014). Building international strategy with formats and formulae in global strategies in retailing: Asian and European experiences. In J. Dawson, M. Mukoyama (Ed.) (252 p.). London, UK: Routledge.

Dupuis, M., \& Prime, N. (1995, May). Culture and internationalization strategies of retail formats a model analysis. Proceedings of the Fifth Annual Congress of the French Marketing Association Reims.

Fernie, J., \& Fernie, S. (1997). The development of a US retail format in Europe: the case of factory outlet cetres. International Journal of Retail and Distribution Management, 25(11), 342-350. https://doi.org/10.1108/09590559710192440

Gandolfi, F., \& Strach, P. (2009). Retail internationalization: gaining insights from the Wal-Mart experience in South Korea. Review of International Comparative Management, 10(1), 187-199.

Goldman, A. (2000). Supermarkets in China: the case of Shanghai. International Review of Retail, Distribution and Consumer Research, 10(1), 1-21. https://doi.org/10.1080/095939600342370

Goldman, A. (2001). The transfer of retail formats into developing economies: the example of China. Journal of Retailing, 77(2), 221-242.

https://doi.org/10.1016/S0022-4359(01)00044-6

Gorton, M., Sauer, J., \& Supatpongkul, P. (2011). Wet markets, supermarkets and the big middlefor food retailing in developing countries: evidence from Thailand. World Development, 39(9), 1624-1637. https://doi.org/10.1016/j.worlddev.2011.02.005

Guy, C. (2001). Internationalisation of large-format retailers and leisure providers in Western Europe: planning and property impacts. International Journal of Retail and Distribution Management, 29(10), 452-461. https://doi.org/10.1108/09590550110405330

Hallsworth, A., de Kervenoael, R., Elms, J., \& Canning, C. (2010). The food superstore revolution: changing times, changing research agendas in the UK. International Review of Retail, Distribution and Consumer Research, 20(1), 135-146. https://doi.org/10.1080/09593960903498276

Humphrey, J. (2007). The supermarket revolution in developing countries: tidal wave or tough competitive struggle?. Journal of Economic Geography, 7(4), 433-450. https://doi.org/10.1093/jeg/lbm008

Jonsson, A. (2010). How maintain a process perspective on retail internationalization: the "IKEA" case. European Retail Research, 24(1), 27-49. https://doi.org/10.1007/978-3-8349-8938-3_2

Lowe, M., \& Wrigley, N. (2009). Innovation in retail internationalisation: Tesco in the USA. The International Review of Retail, Distribution, Consumer Research, 19(4), 331-347. https://doi.org/10.1080/09593960903331337 
Minahan, S., Huddleston, P., \& Bianchi, C. (2012). Costco, Aussie Shopper: a case study of the market entry of an international retailer. The International Review of Retail, Distribution, Consumer Research, 22(5), 507-527. https://doi.org/10.1080/09593969.2012.711253

Mukoyama, M., \& Dawson, J. (2006). Change of retail formula in the retail internationalization process in strategies issues in international retailing. Routledge.

Reardon, T., Henson, S., \& Berdegue, J. (2007). Proactive fast-tracking diffusion of supermarkets in developing countries: implications for market institution and trade. Journal of Economic Geography, 7(4), 391-431. https://doi.org/10.1093/jeg/lbm007

Swoboda, B., Berg, B., \& Dabija, D. C. (2014). International transfer and perception of retail formats: a comparison study in Germany and Romania. International Marketing Review, 31(2), 155-180.

https://doi.org/10.1108/IMR-11-2012-0190

Swoboda, B., \& Elsner, S. (2013). Transferring the retail format successfully into foreign countries. Journal of International Marketing, American Marketing Association, 21(1), 81-109.

https://doi.org/10.1509/jim.12.0148

White, D. W., \& Absher, K. (2007). Positioning of retail stores in Central and Eastern European accession states: standartization versus adaptation. European Journal of Marketing, 41(3/4), 292-306. https://doi.org/10.1108/03090560710728345 